УдК 616.71-007.234-02:616.3-06]-055.2

DOI 10.11603/1811-2471.2019.v.i3.10493

\title{
АНАЛІЗ КІСТКОВО-МЕТАБОЛІЧНИХ ЗМІН ПРИ КОМОРБІДНОСТІ ХРОНІЧНОГО ПАНКРЕАТИТУ ТА ХРОНІЧНОГО ГАСТРОДУОДЕНІТУ В ОСІБ ЧОЛОВІЧОЇ СТАТІ
}

\author{
๑С. М. Андрейчин, Т. В. Бойко, Г. В. Лихацька, В. О. Лихацька \\ Тернопільський начіональний медичний університет імені І. Я. Горбачевського МОЗ України
}

РЕзЮМЕ. В останні роки велику увагу надають вторинному остеопорозу, який виникає на ґрунті коморбідної патології, і, як наслідок, у людей молодого віку.

Мета - вивчити особливості мінеральної щільності кісткової тканини у чоловіків з коморбідною патологією органів травлення.

Матеріал і методи. Обстежено 67 хворих чоловічої статі на поєднану патологію гастродуоденопанкреатичної зони іпечінки та 20 практично здорових осіб. Серед обстежених було 17 хворих $(25,4 \%)$ на хронічний гастродуоденіт (ХГД), 24 (35,8 \%) - на хронічний гастродуоденіт у поєднанні з хронічним панкреатитом (ХП) і 26 (38,8 \%) - на хронічний гастродуоденіт у поєднанні з хронічним панкреатитом на тлі хронічного гепатиту (ХГ). Вік пацієнтів коливався від 20 до 73 років, середній вік - $(43,54 \pm 1,25)$ роки. Із метою кількісної оцінки мінеральної щільності кісткової тканини застосовували двофотонний рентгенівський денситометр (DEXA) для осьового скелета фірми Lunar (США).

Результати. Встановлено, що частота розвитку остеопорозу в групах хворих на поєднану патологію органів травлення є вищою, зокрема, у хворих на ХГД і ХП в поєднанні з ХГ в 4,6 раза, у хворих на ХГД в поєднанні з ХП - у 2,8 раза, порівняно з ХГД. Глибина остеодефіциту у хворих на коморбідну патологію достовірно збільшувалася $(p<0,05)$.

КЛючОВІ СлОВА: мінеральна щільність кісткової тканини; хронічний гастродуоденіт; хронічний панкреатит; хронічний гепатит.

Актуальність проблеми остеопорозу обумовлена значними соціальними та економічними наслідками цієї патології. Сьогодні остеопороз $\epsilon$ основною причиною переломів шийки стегна. Переломи стегнової кістки призводять до зменшення тривалості життя на 12-15 років. Остеопенія - це низька щільність кісткової тканини або низька кісткова маса, стан, при якому у людини спостерігається зменшення кісткової структури, що перевищує нормальну величину для відповідного віку. Остеопенія, якщо їі не зупинити, призводить до остеопорозу, - серйозного захворювання, при якому щільність кістки погіршується настільки, що збільшує ризик руйнування або переломів кісток. Остеопенія зустрічається частіше, ніж остеопороз, що вражає мільйони молодих і середнього віку людей, особливо жінок [1-9].

За висновком експертів ВООЗ, остеопороз посідає третє місце за поширеністю після серцево-судинних захворювань і цукрового діабету [10-15]. Остеопороз - це системне захворювання скелета, що характеризується зниженням кісткової маси і порушенням мікроархітектоніки кісткової тканини, які призводять до значного збільшення ії крихкості i, як наслідок, до збільшення ризику переломів [16-20]. За даними В. В. Поворознюка [7], в Україні близько 3 \% людей страждає на остеопороз та його ускладнення. На остеопороз хворі понад 250 млн людей у всьому світі, в тому числі кожна третя жінка в постменопаузальному періоді. У хворих з пере- ломами кісток остеопороз трапляється в 6570 \% випадків. На думку експертів ВООЗ, остеопороз посідає 4 місце в структурі причин інвалідності та смертності, після інфаркту міокарда, онкопатології й раптової смерті. Згідно з прогнозами ВООЗ, до 2050 року кількість осіб із переломом шийки стегна зросте до 1 млн. В осіб похилого віку 90 \% випадків переломів шийки стегна виникають на тлі остеопорозу. Населення Землі поступово старіє [21-25]. Захворюваність на остеопороз починає збільшуватися в віці >50 років. Остеопороз призводить до значно більшої кількості днів госпіталізації та непрацездатності, ніж інсульт, інфаркт міокарда або рак грудей. Згідно з прогнозами, поширеність остеопорозу в найближчі 50 років подвоїться. Із віком погіршуються «якість старіння» та «якість функції», знижується здатність організму адекватно реагувати на ендогенні та екзогенні впливи. Тому простежуються не тільки загальні тенденції старіння населення, як причина підвищення рівня захворюваності, а й «помолодшання» самого остеопорозу через погіршення екологічної ситуації та внаслідок генетичних порушень. В останні роки велику увагу надають вторинному остеопорозу, який виникає на ґрунті коморбідної патології, i, як наслідок, у людей молодого віку [26].

Хронічні запальні захворювання гастродуоденопанкреатичної зони і печінки супроводжуються зниженням абсорбції мінералів і вітаміну D 
Огляди літератури, оригінальні дослідження, погляд на проблему, випадок з практики, короткі повідомлення в кишечнику, внаслідок чого знижується мінеральна щільність кісткової тканини (МЩКТ), що часто призводить до інвалідизації хворих.

Мета дослідження - вивчити особливості МЩКТ у чоловіків з коморбідною патологією органів травлення.

Матеріал і методи дослідження. Обстежено 67 хворих чоловічої статі на поєднану патологію гастродуоденопанкреатичної зони і печінки та 20 практично здорових осіб. Серед обстежених було 17 хворих (25,4\%) на хронічний гастродуоденіт, 24 (35,8 \%) - на хронічний гастродуоденіт у поєднанні з хронічним панкреатитом і 26 (38,8 \%) на хронічний гастродуоденіт у поєднанні з хронічним панкреатитом на тлі хронічного гепатиту. Вік пацієнтів коливався від 20 до 73 років, в середньому $(43,54 \pm 1,25)$ роки. Діагноз встановлювали згідно з протоколами МОЗ України. Для верифікації діагнозу використовували широкий спектр клінічних і лабораторно-інструментальних обстежень (загальний та біохімічний аналізи крові, сечі, копрограма, імуноферментний аналіз крові на виявлення маркерів вірусних гепатитів та антитіл до Нр, у частини хворих ПЛР на виявлення Нр і вірусів гепатитів B, C, інтрагастральна рН-метрія, ЕГДФС з гістологічним та цитологічним дослідженням, ультразвукове дослідження органів черевної порожнини).

Із метою кількісної оцінки мінеральної щільності кісткової тканини застосовували двофотонний рентгенівський денситометр (DEXA) для осьового скелета фірми Lunar (США). Отримані цифрові дані обробляли методом варіаційної статистики та кореляційного аналізу [27].

Результати й обговорення. Проведені обстеження показали, що у хворих на ХГД нормальна МЩКТ відмічалася у 7 випадках (41,2 \%), остеопенії різних ступенів - у 9 (52,9\%), остеопороз - у 1 (5,9\%); у другої групи пацієнтів (ХГД в поєднанні з ХП) - 6 (25,0 \%), 14 (58,3 \%), 4 (16,7 \%) відповідно.

Таблиця 1. Розподіл хворих чоловічої статі відповідно до змін МЩКТ

\begin{tabular}{|c|c|c|c|c|c|c|}
\hline \multirow{3}{*}{ Групи обстежуваних чоловіків } & \multicolumn{6}{|c|}{ Стан МЩКТ } \\
\hline & \multicolumn{2}{|c|}{ норма } & \multicolumn{2}{|c|}{ остеопенія } & \multicolumn{2}{|c|}{ остеопороз } \\
\hline & a6c. & $\%$ & $\mathrm{a} 6 \mathrm{c}$. & $\%$ & a6c. & $\%$ \\
\hline ХГД & 7 & 41,2 & 9 & 52,9 & 1 & 5,9 \\
\hline ХГД у поєднанні з ХП & 6 & 25,0 & 14 & 58,3 & 4 & 16,7 \\
\hline ХГД і ХП на тлі ХГ & 4 & 15,4 & 15 & 57,7 & 7 & 26,9 \\
\hline
\end{tabular}

Як видно з таблиці 1, найчастіше глибокі зміни остеодефіциту, що відповідають остеопорозу, зустрічалися у групі хворих на ХГД і ХП на тлі ХГ в 1,6 раза більше, ніж у хворих на ХГД на тлі ХП та в 4,6 раза - у хворих на ХГД. Остеопенія у групи пацієнтів з ХГД траплялася у 1,3 раза частіше, порівняно із нормою, а остеопороз - навпаки, зустрічався рідше у хворих з ХГД, ніж у контрольній групі пацієнтів. Остеопенія у групи пацієнтів з ХГД у поєднанні з ХП зустрічалася у 2,3 раза частіше, порівняно із нормою, однак остеопороз у цієї ж групи пацієнтів спостерігали у 1,5 раза рідше, ніж у контрольній групі. У групи пацієнтів з ХГД і ХП на тлі ХГ остеопенія спостерігалася у 3,75 раза частіше, порівняно із контролем, а остеопороз - у 1,75 раза частіше, ніж у контрольній групі.

Крім того варто зазначити, що у групах обстежуваних чоловіків остеопенія в загальному спостерігалася у 3,2 раза частіше, ніж остеопороз. Однак найбільша різниця відмічалася у групі пацієнтів з ХГД: остеопенія спостерігалася у 9 випадках, тоді як остеопороз - лише в 1 випадку. У групі хворих з ХГД у поєднанні з ХП остеопенія зустрічалася у 3,5 раза частіше, ніж остеопороз (14 випадків проти 4 відповідно), а у групі обстежуваних чоловіків з ХГД і ХП на тлі ХГ остеопенія спостерігалася у 2 рази частіше, ніж остеопороз (15 випадків проти 7 відповідно).

Остеопороз зустрічався частіше у групах хворих на поєднану патологію органів травлення, зокрема у хворих на ХГД і ХП в поєднанні з ХГ в 4,6 раза, у хворих на ХГД в поєднанні з ХП - У 2,8 раза, порівняно з ХГД. Також частота розвитку остеопенії була вищою у групах хворих на поєднану патологію органів травлення, зокрема у хворих на ХГД і ХП в поєднанні з ХГ - у 1,09 раза, порівняно з ХГД, а у хворих на ХГД в поєднанні 3 ХП -у 1,1 раза, порівняно з ХГД.

Як видно з даних, наведених у таблиці 2, достовірно нижчі показники виявлені у хворих на ХГД і ХП на тлі ХГ. Так, показник МЩКТ поперекового відділу хребта у 1,02 раза перевищував показник МЩКТ проксимального відділу стегнової кістки. Однак показник Т (у \%) проксимального відділу стегнової кістки був у 1,02 раза вищим, ніж показник Т поперекового відділу хребта. Показник Т (од. станд. відх.) поперекового відділу хребта в 1,44 раза перевищував вказаний показник проксимального відділу стегнової кістки. 
Огляди літератури, оригінальні дослідження, погляд на проблему, випадок з практики, короткі повідомлення Таблиця 2. Зміни МщКТ поперекового відділу хребта та правої стегнової кістки

\begin{tabular}{|l|l|c|c|c|}
\hline \multicolumn{2}{|c|}{ Групи обстежуваних чоловіків } & МЩКТ, г/см² & Т, \% & Т, од. станд. відх. \\
\hline ХГД & 1 & $1,094 \pm 0,028$ & $91,9 \pm 2,2$ & $-0,76 \pm 0,19$ \\
\cline { 2 - 5 } & 2 & $1,001 \pm 0,021$ & $96,6 \pm 1,7$ & $-0,34 \pm 0,18$ \\
\hline ХГД у поєднанні з ХП & 1 & $0,997 \pm 0,041^{*}$ & $84,2 \pm 3,6^{*}$ & $-1,30 \pm 0,34^{*}$ \\
\cline { 2 - 5 } & 2 & $0,940 \pm 0,042^{*}$ & $86,3 \pm 3,9^{*}$ & $-1,07 \pm 0,33^{*}$ \\
\hline ХГД і ХП на тлі ХГ & 1 & $0,928 \pm 0,022^{* *}$ & $80,3 \pm 1,8^{* *}$ & $-1,85 \pm 0,20^{* *}$ \\
\cline { 2 - 5 } & 2 & $0,909 \pm 0,023^{* *}$ & $82,3 \pm 1,9^{* *}$ & $-1,28 \pm 0,20^{* *}$ \\
\hline
\end{tabular}

Примітки: 1.1 - показники МЩКТ поперекового відділу хребта;

2 - показники МЩКТ проксимального відділу стегнової кістки;

* - достовірність різниці між показниками МЩКТ хворих на ХГД і ХГД на тлі ХП;

** - достовірність різниці між показниками МщКТ правої стегнової кістки хворих на ХГД на тлі ХП і ХГД і ХП на тлі ХГ.

Висновки. 1. Частота розвитку остеопорозу $\epsilon$ вищою у групах хворих на поєднану патологію органів травлення, зокрема у хворих на ХГД і ХП в поєднанні з ХГ в 4,6 раза, у хворих на ХГД в поєднанні з ХП - у 2,8 раза порівняно з ХГД.

2. Глибина остеодефіциту достовірно збільшувалася $(p<0,05)$ у хворих на коморбідну патологію.

\section{ЛІТЕРАТУРA}

1. Дефіцит та недостатність вітаміну D у жителів України / В. В. Поворознюк, Н. І. Балацька, В. Я. Муц, О. А. Вдовіна // Боль. Суставы. Позвоночник. - 2011. № 4. - C. 5-13.

2. Орленко В. Л. Остеопороз и эндокринная система витамина D: некоторые аспекты патогенеза и диагностики / В. Л. Орленко // Здоров'я України. - 2012. - С. 65-67.

3. Пирогова В. І. Біохімічні маркери в діагностиці порушень кісткового метаболізму після гістеректомії [Електронний ресурс] / В. І. Пирогова, А. Г. Місюра. - Pежим доступу: http://archive.nbuv.gov.ua/portal/chem_ biol/prmed/2009_3/web_files/Pyrogova.pdf.

4. Плещева А. В. Витамин D и метаболизм: факты, мифы и предубеждения / А. В. Плещева, Е. А. Пигарова, Л. К. Дзеранова // Ожирение и метаболизм. - 2012. № 2. - С. 33-42.

5. Ткачишин В. С. Основні клінічні синдроми при ураженнях травного каналу професійного генезу / В. С. Ткачишин // Сучасна гастроентерологія. - 2008. № 2 (40). - C. 99-102.

6. Effects of bile reflux on gastric mucosal lesions in patients with dyspepsia or chronic gastritis / C. Sheng-Liang, M. Jian-Zhong, C. Zhi-Jun [et al.] // World J. Gastroenterol. 2005. - Vol. 14, No. 11 (18). - P. 2834-2837.

7. Effect of domperidone therapy on nocturnal dyspeptic symptoms of functional dyspepsia patients / C. Sheng-Liang, J. Jie-Ru, X. Ping [et al.] // World J. Gastroenterol. - 2010. - Vol. 7, No. 16 (5). - P. 613-617.

8. Feng X. Disorders of Bone Remodeling / X. Feng, J. M. McDonald // Annu. Rev. Pathol. - 2011. - No. 6. P. $121-145$.

9. Gilbert C. R. Vitamin D deficiency and chronic lung disease / C. R. Gilbert, S. M. Arum, C. M. Smith // Can. Respir. J. - 2009. - Vol. 16, No. 3. - P. 75-80.
Перспективи подальших досліджень. Враховуючи вищенаведене, у пацієнтів з поєднаною патологією органів травлення необхідно проводити ранню діагностику змін МЩКТ з метою запобігання остеопорозу і його наслідкам.

10. Liquid gastric emptying is often abnormal when solid emptying is normal / H. A. Ziessman, P. I. Okolo, G. E. Mullin [et al.] // J. Clin. Gastroenterol. -2009. - Vol. 43, Iss. 7. - P. 639-643.

11. Ma H. J. Quadruple therapy lor eradication of Helicobacter pylori / H. J. Ma, J. L. Wang // World J. Gastroenterol. - 2013. - Vol. 19. - P. 931-935.

12. Management of Helicobacter pylori infection the Maastricht IV. Florence Consensus Report / P. Malfertheiner, F. Megraud, C. O'Morain [et al.] // Gut. - 2012. Vol. 61, No. 5. - P. 646-664.

13. Masaoka T. Gastroparesis: Current concepts and management / T. Masaoka, J. Tack // Gut and Liver. - 2009. Vol. 3, No. 3. - P. 166-173.

14. Methods to assess gastric motility and sensation / P. T. Schmidt, H. Abrahamsson, A. Dolk [et al.] // Scand. J. Gastroenterol. - 2008. - Vol. 43. - P. 1285-1295.

15. McCallum R. W. New techniques for assessment of gastric emptying; Smart-Pill, Breath testing and MRI. Innovations in assessing gastric emptying and new pharmacology in the foregut. Workshop / R. W. McCallum // 9th World Congress OESO. - Monaco, 2008.

16. OLGA can guard the barn / M. Rugge, M. de Boni, G. Pennelli [et al.] // Am. J. Gastroenterol. - 2009. Vol. 104 (12). - P. 3099.

17. OLGA staging for gastritis: a tutorial / M. Rugge, P. Korrea, F. Di Mario [et al.] // Dig. Liver Dis. - 2008. Vol. 40. - P. 650-658.

18. Quigley E. M. M. Gastric motor and sensory function and motor disorders of the stomach / E. M. M. Quigley // Sleisenger \& Fordtran's gastrointestinal and liver disease. - 2002. - Vol. 1. - P. 691-713.

19. Reddymasu S. C. Domperidone: review of pharmacology and clinical applications in gastroenterology / 
Огляди літератури, оригінальні дослідження, погляд на проблему, випадок з практики, короткі повідомлення

S. C. Reddymasu, I. Soykan, R. W. McCallum // Am. J. Gastroenterol. - 2007. - Vol. 102 (9). - P. 2036-2045.

20. Regulatory T cells, inflammation and the allergic response: the role of glucocorticoids and vitamin D / S. Dimeloe, A. Nanzer, K. Ryanna [et al.] // J. Steroid. Biochem. Mol. Biol. - 2010. - Vol. 120. - P. 86-95.

21. Sanjeevi A. Gastric Motility / A. Sanjeevi // Curr. Opin. Gastroenterol. - 2007. - Vol. 23 (6). - P. 625-630.

22. Shiotani A. Evidence that loss of sonic hedgehog is an indicator of Helicobacter pylori-induced atrophic gastritis progressing to gastric cancer / A. Shiotani // Am. J. Gastroenterol. - 2005. - Vol. 100. - P. 581-587.

23. Sipponen P. Importance of atrophic gastritis in diagnostics and prevention of gastric cancer: application of plasma biomarkers / P. Sipponen, D. Y. G. Raham // Scand. J. Gastroenterol. - 2007. - Vol. 42 (1). - P. 2-10.

\section{REFERENCES}

1. Povorozniuk, V.V., Balatskyi, N.I., Muts, V.Ya., \& Vdovina, O.A. (2011). Defitsit ta nedostatnist vitaminu D u zhyteliv Ukrainy [Deficiency and insufficiency of vitamin D among residents of Ukraine]. Bol. Sustavy. Pozvonochnik Pain. Joints. Spine, 4, 5-13 [in Ukrainian].

2. Orlenko, V.L. (2012). Osteoporoz i endokrynna systema vitaminu D: deiaki aspekty patohenezu ta diahnostyky [Osteoporosis and the endocrine system of vitamin D: some aspects of pathogenesis and diagnosis]. Zdorovia Ukrainy - Health of Ukraine, 65-67 [in Ukrainian].

3. Pyrohova, V.I. Biokhimichni markery v diahnostytsi porushenniakh kistkovoho metabolizmu pislia histerektomii [Biochemical markers in the diagnosis of the destruction of bone metabolism in hysterectomy]. Retrieved from: http:// archive.nbuv.gov.ua/portal/chem_biol/prmed/2009_3/ web_files/Pyrogova.pdf [in Ukrainian].

4. Pleshcheva, A.V., Pigarova, E.A. \& Dzeranova, L.K. (2012). Vitamin D i metabolism: fakty, mify i predubezhdeniye [Vitamin D and metabolism: facts, myths and prejudices]. Ozhyreniye i metabolism - Obesity and Metabolism, 2, 33-42 [in Russian].

5. Tkachyshyn, V.S. (2008). Osnovni klinichni syndromy pry urazhenniakh travnoho kanalu profesiinoho henezu [The main clinical syndromes with urethra of the herbal canal of professional genesis]. Suchasna hastroenterolohiia Modern Gastroenterology, 2 (40), 99-102 [in Ukrainian].

6. Sheng-Liang, C., Jian-Zhong, M., \& Zhi-Jun, C. (2005). Effects of bile reflux on gastric mucosal lesions in patients with dyspepsia or chronic gastritis. World J. Gastroenterol., 14, 11 (18), 2834-2837.

7. Sheng-Liang, C., Jie-Ru, J., \& Ping, X. (2010). Effect of domperidone therapy on nocturnal dyspeptic symptoms of functional dyspepsia patients. World J. Gastroenterol., 7, 16 (5), 613-617.

8. Feng, X., \& McDonald, J.M. (2011). Disorders of bone remodeling. Annu. Rev. Pathol., 6, 121-145.

9. Gilbert, C.R., Arum, S.M., \& Smith, C.M. (2009). Vitamin $D$ deficiency and chronic lung disease. Can. Respir. J., $16(3), 75-80$.

10. Ziessman, H.A., Okolo, P.I., \& Mullin, G.E. (2009). Liquid gastric emptying is often abnormal when solid emptying is normal. J. Clin. Gastroenterol., 43 (7), 639-643.
24. Sivarao D. V. Pyloric sphincter dysfunction in nNOSí/i and W/Wv mutant mice: animal models of gastroparesis and duodeno-gastric reflux / D. V. Sivarao, H. Mashimo, R. K. Goyal // Gastroenterology. - 2008. - Vol. 135 (4). P. 1258-1266.

25. The mutagenic potential of duodenoesophageal reflux / J. Theisen, J. H. Peters, M. Fein [et al.] // Ann. Surg. - 2005. - Vol. 241 (1). - P. 63-68.

26. The Sydney system: a new classification of gastritis. 9th Congress of Gastroenterology. Working party reports / J. J. Misiewicz, G. N. J. Tytgat, C. S. Goodwin [et al.]. - Meldurne: Dlackwell, 1990. - P. 1-10.

27. World Health Organization The global burden of disease: 2004 update. - WHO, Geneva, Switzerland, 2008.

11. Ma, H.J., \& Wang, J.L. (2013). Quadruple therapy for eradication of Helicobacter pylori. World J. Gastroenterol., 19, 931-935.

12. Malfertheiner, P., Megraud, F., \& O'Morain, C. (2012). Management of Helicobacter pylori infection - the Maastricht IV. Florence Consensus Report. Gut., 61 (5), 646-664.

13. Masaoka, T., \& Tack, J. (2009). Gastroparesis: Current concepts and management. Gut and Liver., 3 (3), 166-173.

14. Schmidt, P.T., Abrahamsson, H., \& Dolk, A. (2008). Methods to assess gastric motility and sensation. Scand. J. Gastroenterol., 43, 1285-1295.

15. McCallum, R.W. (2008). New techniques for assessment of gastric emptying; Smart-Pill, Breath testing and MRI. Innovations in assessing gastric emptying and new pharmacology in the foregut. Workshop. 9th World Congress OESO. Monaco.

16. Rugge, M., de Boni M., \& Pennelli, G. (2009). OLGA can guard the barn. Am. J. Gastroenterol., 104 (12), 3099.

17. Rugge, M., Korrea, P., \& Di Mario, F. (2008). OLGA staging for gastritis: a tutorial. Dig. Liver Dis., 40, 650-658.

18. Quigley, E.M.M. (2002). Gastric motor and sensory function and motor disorders of the stomach. Sleisenger \& Fordtran's Gastrointestinal and Liver Disease, 1, 691-713.

19. Reddymasu, S.C., Soykan, I. \& McCallum, R.W. (2007). Domperidone: review of pharmacology and clinical applications in gastroenterology. Am. J. Gastroenterol., 102 (9), 2036-2045.

20. Dimeloe, S., Nanzer, A. \& Ryanna, K. (2010). Regulatory $T$ cells, inflammation and the allergic response: the role of glucocorticoids and vitamin D. Steroid. Biochem. Mol. Biol., 120, 86-95.

21. Sanjeevi, A. (2007). Gastric Motility. Curr. Opin. Gastroenterol., 23 (6), 625-630.

22. Shiotani, A. (2005). Evidence that loss of sonic hedgehog is an indicator of Helicobacter pylori-induced atrophic gastritis progressing to gastric cancer. Am. J. Gastroenterol., 100, 581-587.

23. Sipponen, P. \& Raham, D.Y.G. (2007). Importance of atrophic gastritis in diagnostics and prevention of gastric cancer: application of plasma biomarkers. Scand. J. Gastroenterol., 42 (1), 2-10. 
Огляди літератури, оригінальні дослідження, погляд на проблему, випадок з практики, короткі повідомлення

24. Sivarao, D.V., Mashimo, H., \& Goyal, R.K. (2008). Pyloric sphincter dysfunction in nNOSí/í and W/Wv mutant mice: animal models of gastroparesis and duodeno-gastric reflux. Gastroenterology, 135 (4), 1258-1266.

25. Theisen, J., Peters, J.H., \& Fein, M. (2005). The mutagenic potential of duodenoesophageal reflux. Ann. Surg., 241 (1), 63-68.
26. Misiewicz, J.J., Tytgat, G.N.J. \& Goodwin, C.S. (1990). The Sydney system: a new classification of gastritis. gth Congress of Gastroenterology. Working party reports. Meldurne: Dlackwell.

27. (2001) : World Health Organization The global burden of disease: 2004 update. WHO, Geneva, Switzerland, 2008.

\title{
АНАЛИЗ КОСТНО-МЕТАБОЛИЧЕСКИХ ИЗМЕНЕНИЙ ПРИ КОМОРБИДНОСТИ ХРОНИЧЕСКОГО ПАНКРЕАТИТА И ХРОНИЧЕСКОГО ГАСТРОДУОДЕНИТА У ЛИЦ МУЖСКОГО ПОЛА
}

\author{
๑С. М. Андрейчин, Т. В. Бойко, Г. В. Лихацкая, В. О. Лихацкая
}

Тернопольский национальный медицинский университет имени И. Я. Горбачевского

РЕЗЮМЕ. В последние годы большое внимание уделяют вторичному остеопорозу, который возникает на почве коморбидной патологии, и, как следствие, у людей молодого возраста.

Цель - изучить особенности минеральной плотности костной ткани у мужчин с коморбидной патологией органов пищеварения.

Материалы и методы. Обследовано 67 больных мужского пола с совмещенной патологией гастродуоденопанкреатической зоны и печени и 20 практически здоровых лиц. Среди обследованных было 17 больных (25,4 \%) хроническим гастродуоденитом (ХГД), 24 (35,8 \%) - хроническим гастродуоденитом в сочетании с хроническим панкреатитом (ХП) и 26 (38,8 \%) - хроническим гастродуоденитом в сочетании с хроническим панкреатитом на фоне хронического гепатита (ХГ). Возраст пациентов колебался от 20 до 73 лет, средний возраст - $(43,54 \pm 1,25)$ года. С целью количественной оценки минеральной плотности костной ткани применяли двофотонный рентгеновский денситометр (DEXA) для осевого скелета фирмы Lunar (США). Установлено, что частота развития остеопороза выше в группах больных с совмещенной патологией органов пищеварения, в частности у больных ХГД и ХП в сочетании с ХГ в 4,6 раза, у больных ХГД в сочетании с ХП - в 2,8 раза по сравнению с ХГД. Глубина остеодефицита достоверно увеличивалась $(p<0,05)$ у больных коморбидной патологией.

КЛЮчЕВЫЕ СЛОВА: минеральная плотность костной ткани; хронический гастродуоденит; хронический панкреатит; хронический гепатит.

\section{ANALYSIS OF BONE-METABOLIC CHANGES IN COMORBIDITY OF CHRONIC PANCREATITIS AND CHRONIC GASTRODUODENITIS IN MALES}

\author{
@S. M. Andreichyn, T. V. Boiko, H. V. Lykhatska, V. O. Lykhatska \\ I. Horbachevsky Ternopil National Medical University
}

SUMMARY. In recent years, much attention has been paid to secondary osteoporosis, which occurs on the basis of comorbid pathology, and, as a consequence, in young people

The aim - to study the characteristics of bone minaral in men with comorbid pathology of the digestive system.

Material and Methods. 67 male patients with combined pathology of the gastroduodenopancreatic zone and liver and 20 practically healthy persons were examined. The survey included 17 patients $(25.4 \%)$ with chronic gastroduodenitis, $24(35.8 \%)$ with chronic gastroduodenitis in combination with chronic pancreatitis and 26 (38.8\%) with chronic gastroduodenitis in combination with chronic pancreatitis on the background of chronic hepatitis. Patients' ages ranged from 20 to 73 years, with an average age of (43.54 \pm 1.25$)$ years. For quantitative assessment of bone mineral density, a two-photon $\mathrm{x}$-ray densitometer (DEXA) was used for the axial skeleton of Lunar (USA). The incidence of osteoporosis is found to be higher in the groups of patients with combined pathology of digestive organs, in particular in patients with CGD and CP in combination with $\mathrm{CH}$ by 4.6 times, in patients with CGD in combination with $\mathrm{CP}-2.8$ times in comparison with CGD. Depth of osteodeficiency was significantly increased $(p<0.05)$ in patients with comorbid pathology.

KEY WORDS: bone mineral density; chronic gastroduodenitis; chronic pancreatitis; chronic hepatitis. 